\title{
PODWÓJNE UBEZPIECZENIE TEGO SAMEGO PRZEDMIOTU UBEZPIECZENIA PRZY UBEZPIECZENIU ODPOWIEDZIALNOŚCI CYWILNEJ
}

\section{POJĘCIE UMOWY UBEZPIECZENIA}

Zgodnie z art. $805 \S 1$ ustawy z dnia 23 kwietnia 1964 r. Kodeks cywilny ${ }^{1}$, przez umowę ubezpieczenia ubezpieczyciel zobowiązuje się, w zakresie działalności swego przedsiębiorstwa, spełnić określone świadczenie w razie zajścia przewidzianego w umowie wypadku, a ubezpieczający zobowiązuje się zapłacić składkę.

Umowa ubezpieczenia należy do umów dwustronnie zobowiązujących i odpłatnych, bowiem każda ze stron jest zobowiązana do świadczenia na rzecz drugiej. W literaturze i orzecznictwie nie ma zgodności co do tego, czy umowa ubezpieczenia jest umową wzajemną z uwagi na nieadekwatność ekonomiczną przewidzianych w niej świadczeń ${ }^{2}$. Pomimo, że przeważa pogląd przeciwny (,teoria świadczenia

Mgr Magdalena MalarczyK - doktorant w Katedrze Prawa Handlowego, Instytut Prawa Cywilnego, Wydział Prawa i Administracji Uniwersytetu Warszawskiego, ul. Krakowskie Przedmieście 26/28, 00-927 Warszawa; e-mail: ipc@wpia.uw.edu.pl; https://orcid.org/0000-0002-6622-6702

${ }^{1}$ Dz. U. Nr 16, poz. 93 z późn. zm. [dalej cyt.: k.c.].

${ }^{2} \mathrm{~W}$ ocenie autorki pojęcie umowy wzajemnej nie wymaga, aby świadczenia były względem siebie równowartościowe; istotna jest więź funkcjonalna świadczeń obu stron stosunku prawnego, polegająca na uzależnieniu świadczenia jednej strony od świadczenia drugiej strony. Zauważyć trzeba ponadto, że płacenie składki przez ubezpieczającego nie stanowi odpowiednika ewentualnego przyszłego odszkodowania, jakie wpłaci ubezpieczyciel, lecz opłatę za ponoszone przez ubezpieczyciela w czasie trwania umowy ubezpieczenia ryzyko pokrycia ujemnych skutków danych zdarzeń; tak: Z. Radwański, J. Panowicz-Lipska, Zobowiqzania - część szczegółowa, Warszawa: C.H. Beck 2017, s. 306; M. OrLICKI, Umowa ubezpieczenia, Warszawa: C.H. Beck 2002, s. 41-42. Odmienne stanowisko zajął M. KRAJEwsKi, Umowa ubezpieczenia, Warszawa: C.H. Beck 2004, s. 46-50, który umowę ubezpieczenia zakwalifikował do umów gwarancyjnych sensu largo; podobnie M. KALIŃSKI, Umowa ubezpieczenia, [w:] A. Brzozowski, J. Jastrzębski, M. Kaliński [i in.], Zobowiązania. Część szczególowa, Warszawa: Wolters Kluwer Polska 2017, s. 322 oraz SN w wyroku z dnia 20 października 2006 r., sygn. akt IV CSK 125/06, Legalis nr 95812. 
pieniężnego"), w ocenie autorki - umowa ubezpieczenia jest również umową wzajemną. Świadczeniem ubezpieczającego jest składka, którą płaci w związku z zawarciem umowy, świadczeniem ubezpieczyciela zaś jest wypłata odszkodowania, renty albo innego świadczenia $\mathrm{w}$ razie zajścia wypadku ubezpieczeniowego, często w zakresie przewyższającym składkę. Istoty wzajemności umowy ubezpieczenia po stronie ubezpieczyciela można ponadto poszukiwać $\mathrm{w}$ istocie jego świadczenia - ponoszenia ryzyka pokrycia ujemnych skutków objętych ochroną zdarzeń (,teoria ponoszenia ryzyka”) .

Przedmiotem ubezpieczenia majątkowego jest interes majątkowy. Ubezpieczenia majątkowe dzielą się na ubezpieczenia aktywów (np. ubezpieczenia mienia) oraz ubezpieczenia pasywów (np. ubezpieczenie odpowiedzialności cywilnej ${ }^{4}$ ). Szeroka formuła interesu ubezpieczeniowego za granicę przyjmuje legalność (niesprzeczność z prawem) interesu i możliwość jego oceny w pieniądzu.

Ubezpieczenie mienia (ubezpieczenie aktywów) polega na objęciu ochroną ubezpieczeniową określonego umownie składnika mienia ubezpieczonego. Ubezpieczenie OC (ubezpieczenie pasywów) polega na zobowiązaniu ubezpieczyciela do zapłacenia określonego w umowie odszkodowania za szkody wyrządzone osobom trzecim, wobec których odpowiedzialność za szkodę ponosi ubezpieczający lub ubezpieczony (art. $822 \S 1$ k.c.).

Ubezpieczenia majątkowe aktywów i pasywów mimo różnić mają wspólne instytucje, jeśli chodzi o ustalenie odszkodowania. Wspólną instytucją jest suma ubezpieczenia, która jest górną granicą odpowiedzialności ubezpieczyciela; wpływa ona na wysokość składki (art. $824 \S 1$ k.c.) oraz jest powiązana z wartością ubezpieczonego mienia, bowiem w sytuacji zmniejszenia wartości ubezpieczonego mienia każda ze stron umowy ubezpieczenia ma prawo żądać zmniejszenia sumy, co łączy się ze zmniejszeniem składki (art. 824 § 2 i 3 k.c.). Przepis ten wskazuje na dyspozytywny charakter zasady restytucji ubezpieczeń majątkowych.

W ubezpieczeniach OC nie występuje pojęcie wartości ubezpieczeniowej związane z ubezpieczeniem mienia. Wartość ubezpieczenia (ubezpieczeniowa) jest to wartość przedmiotu ubezpieczenia, określana przez strony przy zawieraniu umowy ubezpieczenia. Ubezpieczenie OC zabezpiecza natomiast cały majątek ubezpieczonego przed realizacją pasywów. Wartość ubezpieczeniowa zasadniczo odpowiada wartości rynkowej przedmiotu ubezpieczenia, jednak w praktyce można spotkać przypadki odmienne. Strony w drodze umowy mogą podwyższyć wartość ubezpieczeniową w stosunku do rynkowej wartości przedmiotu ubezpieczenia.

\footnotetext{
${ }^{3}$ M. Krajewski, Umowa ubezpieczenia. Art. 805-834 KC. Komentarz, Warszawa: C.H. Beck 2016, s. 35 i 39-41.

${ }^{4}$ Dalej cyt.: ubezpieczenie OC.
} 
Jeżeli suma ubezpieczenia jest niższa od jego wartości, dochodzi do niedoubezpieczenia. Zakład ubezpieczeń może wtedy odpowiadać za szkodę w takim stosunku, w jakim suma pozostaje do wartości (wariant odpowiedzialności proporcjonalnej), bądź za całą szkodę do wysokości sumy ubezpieczenia (wariant odpowiedzialności na pierwsze ryzyko). Odpowiedzialność zakładu przybiera drugą formę w sytuacji, gdy szkoda ma na ogół charakter częściowy. Zasadniczo poza sporem pozostaje, że w braku odmiennego postanowienia umowy wariant ten przyjmuje się za obowiązujący ${ }^{5}$. Wątpliwości budzi zaś możliwość przyjęcia w umowie ubezpieczenia systemu odpowiedzialności proporcjonalnej. W części orzecznictwa i literatury prezentowane jest stanowisko, że postanowienie takie należy uznać za niedozwolone postanowienie umowne ${ }^{6}$ oraz za wykraczające poza granicę swobody umów ${ }^{7}$. Pojawiły się jednakże głosy wskazujące, że w umowie ubezpieczenia możliwe jest zastosowanie systemu odpowiedzialności proporcjonalnej, które obowiązują przecież $\mathrm{w}$ ubezpieczeniach morskich oraz $\mathrm{w}$ systemach prawnych większości państw europejskich ${ }^{8}$. Niezależnie jednak od wariantu odpowiedzialności towarzystwa suma ubezpieczenia nie ulega wyczerpaniu wskutek kolejnych wypadków ubezpieczeniowych, zaistniałych w okresie ochrony ubezpieczeniowej, chyba że umowa stanowi inaczej. Jeżeli suma ubezpieczenia przewyższa wartość, dochodzi do nadubezpieczenia.

Gdy ubezpieczyciel zapłaci odszkodowanie, roszczenie ubezpieczającego lub ubezpieczonego przeciwko osobie trzeciej odpowiedzialnej za szkodę przechodzi z mocy prawa na ubezpieczyciela do wysokości zapłaconego ubezpieczenia (regres ubezpieczeniowy, cessio vi legis). W sytuacji, gdy ubezpieczyciel pokrył jedynie część szkody, ubezpieczonemu przysługuje co do pozostałej części pierwszeństwo zaspokojenia przed ubezpieczycielem (nemo subrogat contra se, art. $828 \S 1$ k.c. W zW. z art. $518 \S 1$ pkt 4 k.c. $)^{9}$.

\footnotetext{
${ }^{5}$ Wyrok Sądu Najwyższego z dnia 16 października 2014 r., sygn. akt III CSK 302/13, Legalis nr 1126749 .

${ }^{6}$ Tamże; wyrok Sądu Apelacyjnego w Krakowie z dnia 9 stycznia 2015 r., sygn. akt I ACa 1388/14, Legalis nr 1213588.

${ }^{7}$ C. OrŁowski, Dopuszczalność stosowania zasad proporcji w sytuacji niedoubezpieczenia, „Monitor Ubezpieczeniowy” 50 (2012), s. 22.

${ }^{8}$ Krajewski, Umowa ubezpieczenia. Art. 805-834, s. 537.

${ }^{9}$ KaLiŃsKi, Umowa ubezpieczenia, s. 330-334.
} 


\section{INSTYTUCJA PODWÓJNEGO UBEZPIECZENIA W KODEKSIE CYWILNYM. ISTNIENIE LUKI W PRAWIE W PRZYPADKU PODWÓJNEGO UBEZPIECZENIA ODPOWIEDZIALNOŚCI CYWILNEJ}

Podwójne ubezpieczenie ma miejsce, gdy ten sam przedmiot ubezpieczenia w tym samym czasie jest ubezpieczony od tego samego ryzyka w dwóch lub więcej zakładach ubezpieczeń na sumy, które łącznie przewyższają jego wartość ubezpieczeniową. Instytucja podwójnego ubezpieczenia nie ma miejsca, gdy dwa podmioty zawrą dwie umowy ubezpieczenia, nawet jeżeli będą dotyczyły tego samego przedmiotu ubezpieczenia ${ }^{10}$. W praktyce $\mathrm{z}$ podwójnym ubezpieczeniem można się spotkać m.in. w związku z nabyciem pojazdu, który jest już ubezpieczony, zawarciem nowej polisy i niewypowiedzeniem poprzedniej. Ubezpieczający często nie zdają sobie sprawy, że korzystają z podwójnego ubezpieczenia.

W przypadku podwójnego ubezpieczenia dochodzi do nadubezpieczenia, gdyż po dodaniu sum ubezpieczenia określonych w każdej z umów ubezpieczenia kwota ta będzie przewyższać wartość ubezpieczeniową. Poszkodowany nie może jednak uzyskać dwóch odszkodowań - granicą jego roszczenia jest wysokość szkody. Wypłata wyższych sum prowadziłaby do bezpodstawnego wzbogacenia ubezpieczonego, a tym samym zaprzeczałaby istocie i celowi ubezpieczenia gospodarczego.

Ustawodawca w dziale II k.c. zatytułowanym „Ubezpieczenia majątkowe” przewidział regulację dotyczącą podwójnego ubezpieczenia. W świetle art. $824^{1}$ $\S 2$ k.c. z instytucją podwójnego ubezpieczenia można spotkać się w sytuacji, gdy dany przedmiot ubezpieczenia jest ubezpieczony przez tego samego ubezpieczonego w ramach kilku umów ubezpieczenia. Między ubezpieczycielami każdy z nich odpowiada w takim stosunku, w jakim przyjęta przez niego suma ubezpieczenia pozostaje do łącznych sum wynikających z podwójnego lub wielokrotnego ubezpieczenia.

Brak jest przepisu prawnego, który można by zastosować wprost do regresu między ubezpieczycielami w przypadku podwójnego ubezpieczenia OC. Z uwagi na fakt, że art. $824^{1} \S 2$ k.c. posługuje się pojęciem wartości ubezpieczeniowej, która występuje jedynie w ubezpieczeniach mienia, brak jest podstawy prawnej roszczenia regresowego ubezpieczyciela, który zlikwidował szkodę, o zwrot wypłaconego świadczenia w części, która przypada na pozostałego ubezpieczyciela. Jednocześnie brak jest wątpliwości, że ubezpieczający ma prawo żądać od każdego z ubezpieczycieli wypłaty odszkodowania, którego łączna wysokość nie może

${ }^{10}$ Uchwała Sądu Najwyższego z dnia 30 listopada 2005 r., sygn. akt III CZP 96/05, Legalis nr 71457. 
jednak przekroczyć doznanej przez niego szkody (art. $822 \S 1$ k.c.). Z uwagi na niezupełność regulacji prawa cywilnego należy poszukać w drodze wykładni podstawy prawnej dla przedmiotowego roszczenia ubezpieczyciela.

Dokonując wykładni językowej art. $824^{1}$ k.c. niemożliwe jest zastosowanie tego przepisu do ubezpieczenia OC. Wynik takiej wykładni jest jednak nie do przyjęcia, ponieważ prowadziłby do nieusprawiedliwionej faworyzacji tego zakładu ubezpieczeń, który otrzymywałby składki od ubezpieczającego, a w wyniku losowego wyboru ubezpieczającego (lub poszkodowanego), wobec kogo skierować żądanie wypłaty ubezpieczenia, zostałby zwolniony z obowiązku spełnienia swojego podstawowego obowiązku wynikającego z umowy ubezpieczenia - zapłaty odszkodowania. Aby poszukać podstawy prawnej do przedmiotowego regresu między ubezpieczycielami należy posłużyć się wykładnią oraz rozważyć, czy brak przedmiotowego przepisu stanowi świadomy zabieg ustawodawcy, czy też istnieje luka $\mathrm{w}$ prawie.

W myśl $\S 10$ ust. 5 uchylonego już rozporządzenia Ministra Finansów z dnia 9 grudnia 1992 r. w sprawie ogólnych warunków obowiązkowego ubezpieczenia odpowiedzialności cywilnej posiadaczy pojazdów mechanicznych za szkody powstałe w związku z ruchem tych pojazdów ${ }^{11}$, jeżeli ubezpieczono odpowiedzialność cywilną posiadacza tego samego pojazdu mechanicznego na ten sam okres u dwóch lub więcej ubezpieczycieli, każdy z nich odpowiadał za wyrządzoną w tym czasie przez posiadacza lub kierującego pojazdem szkodę, proporcjonalnie do określonej przez niego w umowie ubezpieczenia sumy gwarancyjnej.

Tożsame rozwiązanie znalazło się w $\S 10$ ust. 5 uchylonego rozporządzenia Ministra Finansów z dnia 24 marca 2000 r. w sprawie ogólnych warunków obowiązkowego ubezpieczenia odpowiedzialności cywilnej posiadaczy pojazdów mechanicznych za szkody powstałe w związku z ruchem tych pojazdów ${ }^{12}$, które to uchyliło wyżej wymienione rozporządzenie z dnia 9 grudnia 1992 r. Rozporządzenie to również zostało uchylone w związku z uchyleniem jego podstawy przez ustawę z dnia 22 maja 2003 r. o działalności ubezpieczeniowej ${ }^{13}$, która wprowadziła art. $824^{1}$ k.c. Obowiązujące brzmienie art. $824^{1}$ k.c. zawdzięcza art. 1 pkt 21 ustawy z dnia 13 kwietnia 2004 r. o zmianie ustawy - Kodeks cywilny oraz zmianie niektórych innych ustaw ${ }^{14}$. Zgodnie z treścią art. $824^{1}$ k.c. w brzmieniu obowiązującym przed 10 sierpnia 2007 r., uprawniony do odszkodowania miał w stosunku do każdego z ubezpieczycieli roszczenie o zapłatę części odszkodowania

\footnotetext{
${ }^{11}$ Dz. U. Nr 96, poz. 475 z późn. zm.

${ }^{12}$ Dz. U. Nr 26, poz. 310.

${ }^{13}$ Dz.U. Nr 124, poz. 1151 z późn. zm.

${ }^{14}$ Dz.U. z 2007, Nr 82, poz. 557.
} 
do kwoty obliczanej z proporcji wynikającej z sumy ubezpieczenia, do łącznych sum ubezpieczenia wynikających z podwójnego czy wielokrotnego ubezpieczenia.

Regulacja podwójnego ubezpieczenia OC, jaka znalazła się w wymienionych aktach normatywnych, co prawda rozwiązywała problem podwójnego ubezpieczenia, jednak spotykała się z negatywnymi komentarzami dotyczącymi poziomu ochrony ubezpieczającego i poszkodowanego. W konsekwencji ustawodawca zdecydował się znowelizować art. $824^{1}$ k.c. Zmiana przepisu miała na celu poprawić sytuację ubezpieczonego (ubezpieczającego), przy respektowaniu zasady, że odszkodowanie nie może być wyższe od poniesionej szkody, uprawniony może żądać jego zapłaty od jednego lub obu (lub względnie wielu) ubezpieczycieli, natomiast zasada stosunkowego podziału odpowiedzialności między ubezpieczycielami dotyczy tylko ich wzajemnych rozliczeń1 ${ }^{15}$. Brak jest podstaw do przyjęcia, że nowelizacja podyktowana była potrzebą likwidacji podstawy prawnej do przeprowadzenia między ubezpieczycielami rozliczeń regresowych.

Ustawodawca, nowelizując art. $824^{1}$ k.c., nie zdecydował się jednak uregulować problemu podwójnego ubezpieczenia w ubezpieczeniu odpowiedzialności cywilnej. Mając na uwadze proces legislacyjny, ratio legis przepisu oraz przepisy k.c. dotyczące ubezpieczeń (wykładnia systemowa) - należy dojść do wniosku, że brak uregulowania kwestii regresu między ubezpieczycielami w przypadku podwójnego ubezpieczenia OC nie jest celowym zabiegiem ustawodawcy, a luką w prawie.

\section{WNIOSKOWANIE PER ANALOGIAM - POSZUKIWANIE PODSTAWY PRAWNEJ ROSZCZENIA REGRESOWEGO UBEZPIECZYCIELA OC WZGLĘDEM DRUGIEGO UBEZPIECZYCIELA}

\subsection{UWAGI WSTĘPNE. POTRZEBA POSZUKIWANIA PODSTAWY PRAWNEJ ROSZCZENIA W DRODZE ANALOGII}

O potrzebie wypełnienia luki w prawie w postaci braku przepisu, na podstawie którego jeden z ubezpieczycieli miałby możliwość skierować roszczenie do drugiego ubezpieczyciela, w sytuacji gdy obaj są zobowiązani na podstawie zawartej umowy ubezpieczenia odpowiedzialności cywilnej do naprawienia szkody wyrządzonej poszkodowanemu, świadczą względy etyczne, celowościowe, reguły

\footnotetext{
${ }^{15}$ Rządowy projekt ustawy o zmianie ustawy - Kodeks cywilny, ustawy o działalności ubezpieczeniowej oraz ustawy o ubezpieczeniach obowiązkowych, Ubezpieczeniowym Funduszu Gwarancyjnym i Polskim Biurze Ubezpieczycieli Komunikacyjnych, Druk sejmowy nr 353 z dnia 16 lutego 2006 r. i nr 353 - A z dnia 31 maja 2006, Sejm V Kadencji, [w:] orka.sejm.gov.pl [dostęp: 20.10.2018].
} 
słuszności oraz zasady racjonalnego funkcjonowania porządku prawnego. Gdyby praktycy poprzestali jedynie na wykładni językowej przepisów k.c. dotyczących ubezpieczeń, nie znaleźliby przepisu, na podstawie którego można by przedmiotowe powództwo wytoczyć. Ochrona ubezpieczeniowa ma zaś charakter obiektywny - oznacza to, że nie zależy od tego, czy uprawniony zwróci się z roszczeniem najpierw do tego, czy też do innego ubezpieczyciela. Ryzykiem nie jest działanie uprawnionego, lecz zaistnienie zdarzenia wywołującego szkodę i jego zaistnienie aktualizuje obowiązek ubezpieczyciela pokrycia odszkodowania.

W przypadku wyrządzenia szkody przez osobę posiadającą podwójne ubezpieczenie OC, dwóch ubezpieczycieli zobowiązanych jest do zapewnienia ochrony ubezpieczeniowej. Brak możliwości poszukiwania sposobu na wypełnienie przedmiotowej luki w prawie spowodowałoby, że pomimo ważnej umowy ubezpieczenia, która jest umową odpłatną, dwustronnie zobowiązującą oraz - w ocenie autorki - wzajemną, w stosunku do jednego z ubezpieczycieli nie istniałby ekwiwalent świadczenia ubezpieczającego $\mathrm{w}$ postaci ponoszenia ryzyka pokrycia negatywnych skutków zaistnienia objętego ochroną wypadku. Jeżeli ubezpieczyciel pokrył szkodę powinien mieć prawo poszukiwania regresu, jeśli istnieje jeszcze jakiś podmiot, który ponosi chociaż część odpowiedzialności.

Za potrzebą poszukiwania podstawy prawnej świadczy ratio legis nowelizacji art. $824^{1}$ k.c. Przyjęcie stanowiska o braku podstawy prawnej do rozliczeń między ubezpieczycielami spowodowałoby, że ubezpieczyciele zwlekaliby z wypłatami odszkodowań, czy też zachęcali poszkodowanych do skierowania swoich roszczeń do innych ubezpieczycieli, licząc, że poszkodowany zgłosi szkodę w innym towarzystwie i szkoda zostanie zlikwidowana przez inny podmiot. W taki sposób doszłoby pośrednio do naruszenia interesów samych poszkodowanych, czemu próbował zapobiec ustawodawca, nowelizując art. $824^{1}$ k.c.

Mając na uwadze potrzebę znalezienia podstawy prawnej roszczenia regresowego ubezpieczyciela odpowiedzialności cywilnej w sytuacji podwójnego ubezpieczenia, należy rozważyć możliwość zastosowania w drodze analogii art. 518 k.c., art. 376 $\S 1$ k.c., art. 441 k.c., art. 828 k.c., art. 405 k.c. oraz art. $824^{1}$ k.c.

\subsection{MOŻLIWOŚĆ ZASTOSOWANIA ART. 518 K.C.}

Rozważając ewentualne podstawy roszczenia regresowego ubezpieczyciela OC względem pozostałego ubezpieczyciela, rozważyć należy możliwość analogicznego zastosowania art. 518 k.c. W ocenie autorki brak jest jednak podstaw, aby zastosować art. 518 k.c. w przypadku podwójnego ubezpieczenia OC. Art. 518 k.c. dotyczy przypadków wstąpienia z mocy prawa (ex lege) osoby trzeciej, spłacającej 
wierzyciela, w prawa zaspokojonego wierzyciela (cessio legis, podstawienie) ${ }^{16}$. W myśl art. $518 \S 1$ pkt 4 k.c., osoba trzecia, która spłaca wierzyciela, nabywa spłaconą wierzytelność do wysokości dokonanej zapłaty, jeżeli to przewidują przepisy szczególne. Owym przepisem szczególnym jest art. 828 k.c. regulujący regres ubezpieczeniowy w ubezpieczeniach majątkowych. $\mathrm{Z}$ uwagi na istnienie przepisu art. 828 k.c., będącego lex specialis na gruncie ubezpieczeń gospodarczych, niezasadne jest stosowanie w drodze analogii art. 518 k.c. już z tej przyczyny.

\subsection{MOŻLIWOŚĆ ZASTOSOWANIA ART. 828 K.C.}

Kolejnym przepisem, który należy rozważyć jako ewentualną podstawę roszczenia regresowego zakładu ubezpieczeń w przypadku podwójnego ubezpieczenia OC jest art. 828 k.c. Zgodnie z art. 828 k.c., o ile nie umówiono się inaczej, z dniem zapłacenia odszkodowania ubezpieczeniowego przez ubezpieczyciela (zakład ubezpieczeń) przechodzą na niego (do wysokości dokonanej zapłaty) roszczenia ubezpieczającego do osób trzecich, odpowiedzialnych z tytułu wyrządzenia szkody, za którą wypłacono odszkodowanie.

W ocenie autorki brak jest możliwości zastosowania tego przepisu w drodze analogii do przedmiotowego roszczenia. W orzecznictwie istnieje jednolite stanowisko, że podstawą regresu w dziedzinie ubezpieczenia OC kierowanego przez zakład ubezpieczeń do sprawcy szkody jest przepis szczególny, a nie art. 828 k.c. ${ }^{17}$ Argumentacja ta znajduje również zastosowanie do roszczenia regresowego ubezpieczyciela OC względem pozostałego ubezpieczyciela. Zastosowanie art. 828 k.c. stałoby także w opozycji z ideą podwójnego ubezpieczenia - towarzystwo, które wypłaciło poszkodowanemu świadczenie, miałoby roszczenie o zwrot pełnej kwoty, którą wypłaciło poszkodowanemu, a nie stosownej jej części.

\subsection{MOŻLIWOŚĆ ZASTOSOWANIA ART. 405 K.C.}

Jako podstawę roszczenia regresowego ubezpieczyciela przy podwójnym ubezpieczeniu OC należy rozważyć również art. 405 k.c., jednak w ocenie autorki przepis ten także nie znajduje zastosowania. Zgodnie z jego treścią, kto bez podstawy prawnej uzyskał korzyść majątkową kosztem innej osoby, obowiązany jest do wydania korzyści w naturze, a gdyby to nie było możliwe, do zwrotu jej wartości.

${ }^{16}$ P. Sobolewski, Komentarz do art. 518 k.c., [w:] Kodeks cywilny. Komentarz, red. K. Osjada, Legalis/el. 2018.

${ }^{17}$ Wyrok Sądu Najwyższego z dnia 9 października 2002 r., sygn. akt IV CKN 1409/00, Legalis nr 275101; wyrok Sądu Najwyższego z dnia 18 listopada 2005 r., sygn. akt IV CKN 203/05, [w:] www.saos.org.pl [dostęp: 31.10.2018]. 
Nie ma wątpliwości, że dwa lub kilka towarzystw w przypadku podwójnego lub wielokrotnego ubezpieczenia OC są potencjalnie zobowiązane do spełnienia analogicznego świadczenia (naprawienie szkody wyrządzonej w uszkodzonym pojeździe) na podstawie różnych tytułów prawnych (różnych własnych umów ubezpieczenia zawartych z ubezpieczonym).

U obu ubezpieczycieli występuje jednak podstawa prawna spełnionego świadczenia. Ubezpieczyciel, który wypłacił odszkodowanie spełnia własne zobowiązanie, którego ekwiwalentem jest uiszczona przez ubezpieczonego składka, nie zaś cudzy dług. Jeżeli przesłanki wypłaty odszkodowania zrealizowane zostały względem pierwszego, doszło do tego na podstawie stosunku obligacyjnego łączącego strony i są konsekwencją odpowiedzialności ubezpieczyciela, jako ekwiwalentu płaconej składki, skalkulowanej w stosunku do indywidualnie określonego względem ubezpieczonego w tej umowie ryzyka. Nie zachodzi zatem względem pozostałego towarzystwa bezpodstawne wzbogacenie tylko dlatego, że poszkodowany nie zdecydował się u niego zlikwidować szkody.

Ponadto przepisy o bezpodstawnym wzbogaceniu nie dawałyby możliwości dla określenia, w jakim zakresie regres przysługuje. W konsekwencji art. 405 k.c. nie może znaleźć zastosowania.

\subsection{MOŻLIWOŚĆ ZASTOSOWANIA PRZEPISÓW DOTYCZĄCYCH} ODPOWIEDZIALNOŚCI SOLIDARNEJ - ART. 376 § 1 K.C. ORAZ ART. 441 K.C.

Za podstawę roszczeń regresowych można wskazać także przepisy dotyczące odpowiedzialności solidarnej - art. $376 \S 1$ k.c. oraz art. 441 k.c. W ocenie autorki przepisy te także nie mogą znaleźć zastosowania, bowiem odpowiedzialność odszkodowawcza sprawcy szkody i jego ubezpieczyciela w zakresie OC stanowi odpowiedzialność in solidum.

Odpowiedzialność in solidum, zwana również solidarnością niewłaściwą, nieprawidłową, niezupełną lub przypadkową, nie jest uregulowana w ustawie, jednak jest dopuszczalna w świetle orzecznictwa Sądu Najwyższego oraz literatury. W praktyce występują sytuacje, w których kilka podmiotów - na podstawie odrębnych stosunków prawnych - jest zobowiązanych do naprawienia szkody, przy czym spełnienie świadczenia przez jedną osobę zwalnia pozostałe z obowiązku świadczenia względem poszkodowanego, mimo że nie występuje solidarność bierna ze względu na brak stosownego uregulowania w ustawie lub w umowie ${ }^{18}$.

W ubezpieczeniach OC, w razie zawarcia kilku takich umów, towarzystwa ubezpieczeniowe nie ponoszą solidarnej odpowiedzialności, każdy z ubezpieczycieli

\footnotetext{
${ }^{18}$ Uchwała Sądu Najwyższego z dnia 17 lipca 2007 r., sygn. akt III CZP 66/07, Legalis nr 84025.
} 
odpowiada według reguł odpowiedzialności in solidum. Brak ustawowego uregulowania kwestii wielości osób zobowiązanych wobec tego samego wierzyciela, który może uzyskać tylko jedno odszkodowanie nie stoi na przeszkodzie uznaniu, że pomiędzy zobowiązanymi powstaje więź prawna, będąca źródłem uprawnień i obowiązków w tym stosunku wewnętrznym.

Dominujący w doktrynie i orzecznictwie jest pogląd, że brak wyraźnych przepisów przewidujących roszczenie regresowe nie oznacza, że istnienie takiego roszczenia należy wykluczyć ${ }^{19}$. Wówczas w rachubę będzie wchodził regres w znaczeniu szerokim. Pojęciem tym obejmuje się wszystkie te przypadki, w których dłużnik, zaspokoiwszy wierzyciela, domaga się od innej osoby zwrotu swego świadczenia, niezależnie od tytułu uzasadniającego to prawo. Wspólną cechą tych instytucji jest to, że jedna osoba spełniła świadczenie, które w całości bądź w części obciążało inną. Zobowiązania in solidum nie można zakwalifikować jako regresu sensu stricto (brak podstawy ustawowej bądź umownej), lecz jako regres sensu largo.

Zasadniczo literatura i orzecznictwo dopuszczają możliwość stosowania w drodze analogii do odpowiedzialności in solidum przepisów dotyczących roszczeń regresowych przy odpowiedzialności solidarnej, przy jednoczesnym zastrzeżeniu, że chodzi o przepisy które odpowiadają celowi i charakterowi danego stosunku prawnego ${ }^{20}$.

W sytuacji podwójnego ubezpieczenia OC i naprawienia szkody wyłącznie przez jednego z ubezpieczycieli powstaje pomiędzy zakładami ubezpieczeń sui generis stosunek wewnętrzny, który hipotetycznie uzasadniałby dokonanie następnie wzajemnych rozliczeń pomiędzy nimi w drodze regresu w rozumieniu szerokim. W ocenie autorki brak jest jednak podstaw, aby do odpowiedzialności ubezpieczycieli w przypadku podwójnego ubezpieczenia OC, stosować przepisy dotyczące odpowiedzialności solidarnej (art. $376 \S 1$ k.c. i art. 441 k.c.), bowiem nie odpowiadają one celowi i charakterowi stosunku łączącego ubezpieczycieli.

W świetle art. $376 \S 1$ k.c., jeżeli jeden z dłużników solidarnych spełnił świadczenie, treść istniejącego między współdłużnikami stosunku prawnego rozstrzyga

${ }^{19}$ Wyrok Sądu Okręgowego w Krakowie z dnia 3 grudnia 2014 r., sygn. akt II Ca 1720/14, [w:] www.saos.org.pl [dostęp: 31.10.2018]; wyrok Sądu Apelacyjnego w Krakowie z dnia 10 maja 2017 r., sygn. akt I ACa 1615/16, Legalis nr 1713168; uchwała Sądu Najwyższego z dnia 27 kwietnia 2001 r., sygn. akt III CZP 5/01, OSNC 2001/11/161; uchwała pełnego składu Izby Cywilnej Sądu Najwyższego z dnia 8 października 2010 r., sygn. akt III CZP 35/10, Legalis nr 248464.

${ }^{20}$ Uchwała Sądu Najwyższego z dnia 22 listopada 1978 r., sygn. akt III CZP 76/78, Legalis nr 21190; uchwała składu siedmiu sędziów Sądu Najwyższego z dnia 9 marca 1974 r., sygn. akt III CZP 75/73, Legalis nr 17826; wyrok Sądu Najwyższego z dnia 18 grudnia 1968, sygn. akt II CR 409/68, Legalis nr 13768; uchwała Sądu Najwyższego z dnia 7 kwietnia 1975 r., sygn. akt III 6/75, OSNCP 1976, nr 2, poz. 27; uchwała Sądu Najwyższego z dnia 17 lipca 2007 r., sygn. akt III CZP 66/07, Legalis nr 84025. 
o tym, czy i w jakich częściach może on żądać zwrotu od współdłużników. Jeżeli z treści tego stosunku nie wynika nic innego, dłużnik, który świadczenie spełnił, może żądać zwrotu w częściach równych.

Przepis ten dotyczy solidarnej odpowiedzialności, zatem już z tej przyczyny pozostaje w sprzeczności z istotą solidarności nieprawidłowej. Brak jest również możliwości analogicznego zastosowania tego przepisu do odpowiedzialności in solidum ubezpieczycieli w podwójnym ubezpieczeniu OC. Ze stosunku wewnętrznego łączącego dłużników, którego istnienie charakteryzuje odpowiedzialność solidarną, może wynikać rozłożenie ciężaru odszkodowawczego pomiędzy współzobowiązanymi, dopiero gdy z niego nic nie wynika, ciężar ten ponoszą wszyscy dłużnicy w częściach równych. Ustawodawca, jak się wydaje, wyszedł z założenia, że reguła równego rozłożenia ciężaru świadczenia najlepiej odpowiada interesowi stron. W przypadku odpowiedzialności in solidum brak jest stosunku wewnętrznego, brak jest również podstaw do przyjęcia, aby ubezpieczyciele mieliby odpowiadać w częściach równych.

Istnieje argumentacja, zgodnie z którą za podstawę roszczeń regresowych może służyć art. 441 k.c. Zgodnie z treścią tego przepisu, jeżeli kilka osób ponosi odpowiedzialność za szkodę wyrządzoną czynem niedozwolonym, ich odpowiedzialność jest solidarna ( $(1)$. Jeżeli szkoda była wynikiem działania lub zaniechania kilku osób, ten, kto szkodę naprawił, może żądać od pozostałych zwrotu odpowiedniej części zależnie od okoliczności, a zwłaszcza od winy danej osoby oraz od stopnia, w jakim przyczyniła się do powstania szkody (§ 2).

Sąd Najwyższy przyjął, że tożsamość pojęciowa szkody w rozumieniu prawa cywilnego i ubezpieczeniowego oraz jednolitość zasad rządzących ustaleniem wysokości świadczeń odszkodowawczych na gruncie prawa cywilnego i w ramach odpowiedzialności gwarancyjnej ubezpieczyciela sprawia, że ubezpieczyciel ponosi także skutki uregulowania zawartego w art. $441 \S 1$ k.c. ${ }^{21}$ Solidarna odpowiedzialność ex lege, wynikająca z art. 441 k.c., dotyczy wprost tylko sytuacji, gdy źródłem odpowiedzialności każdego z dłużników jest czyn niedozwolony. Zasadniczo umykają spod tej regulacji bezpośrednio wszystkie te stany faktyczne, w których źródła odpowiedzialności zobowiązanych (dłużników) są odmienne. $\mathrm{Z}$ tej przyczyny oraz z uwagi na uregulowanie solidarnej odpowiedzialności, art. 441 k.c. nie może być podstawą przedmiotowego roszczenia.

Odpowiedzialność współodpowiedzialnych ubezpieczycieli nie jest oparta na odpowiedzialności deliktowej. Ubezpieczyciel, który wypłacił odszkodowanie, spełnił świadczenie na podstawie umowy, delikt zaś jest jedynie przesłanką aktualizacji

${ }^{21}$ Wyrok Sądu Najwyższego z dnia 20 stycznia 2000 r., sygn. akt II CKN 656/98, Legalis nr 354561 . 
odpowiedzialności ubezpieczyciela; do drugiego z ubezpieczycieli poszkodowany żądania takiego nie skierował, zatem ubezpieczyciel ten nie miał żadnych podstaw do likwidacji szkody oraz wypłaty odszkodowania. W przypadku drugiej umowy ubezpieczenia nie zaistniało zdarzenie ubezpieczeniowe, powodujące wypłatę ubezpieczenia, drugi zakład ubezpieczeń ponosić zatem może odpowiedzialność jedynie kontraktową z tytułu odpowiedzialności in solidum za szkodę.

Ponadto niezależnie od powyższych argumentów, regulacja art. 441 k.c. stanowi o wyrządzeniu szkody czynem niedozwolonym przez kilka osób, tymczasem szkodę w omawianym przypadku wyrządza jedna osoba, ubezpieczona u dwóch lub więcej ubezpieczycieli. Dodatkowo, stosując art. 441 k.c. brak jest możliwości ustalenia proporcji winy sprawcy szkody i w konsekwencji proporcji odpowiedzialności ubezpieczycieli za szkodę.

Zastosowanie art. 441 k.c. nie jest także rozwiązaniem najbardziej adekwatnym. Ustawodawca instytucję podwójnego ubezpieczenia zawarł w art. $824^{1}$ k.c. - przy ubezpieczeniu mienia. W przypadku istnienia przepisu bliższego instytucji podwójnego ubezpieczenia OC uzasadnione będzie zastosowanie tej normy, która na gruncie ubezpieczeń majątkowych ma charakter lex specialis w stosunku do art. 441 k.c. i jest normą bliższą konstrukcji odpowiedzialności in solidum.

\section{WYKŁADNIA PRZEPISU ART. $824^{1}$ K.C. W ZAKRESIE MOŻLIWOŚCI JEGO ZASTOSOWANIA W DRODZE ANALOGII DO UBEZPIECZENIA OC}

Wykluczenie powyższych przepisów otwiera drogę do poszukiwania innych podstaw prawnych do rozliczeń między dłużnikami in solidum w sytuacji, gdy jeden z nich spełnił całe świadczenie. Pomimo istnienia wielu kontrargumentów, należy podzielić tezę Sądu Najwyższego zaprezentowaną w uchwale z dnia 13 maja 2016 r. $^{22}$, że do regresu między ubezpieczycielami w przypadku podwójnego ubezpieczenia przy ubezpieczeniu odpowiedzialności cywilnej stosuje się w drodze analogii art. $824^{1}$ k.c. Również należy zaakceptować uzasadnienie uchwały Sądu Najwyższego, uzupełniając je o dodatkową argumentację.

Zgodnie $\mathrm{z}$ art. $824^{1} \S 1$ k.c. w obowiązującym brzmieniu, o ile nie umówiono się inaczej, suma pieniężna wypłacona przez ubezpieczyciela z tytułu ubezpieczenia nie może być wyższa od poniesionej szkody. W świetle $\S 2$ tego przepisu, jeżeli ten sam przedmiot ubezpieczenia w tym samym czasie jest ubezpieczony od tego samego ryzyka u dwóch lub więcej ubezpieczycieli na sumy, które łącznie przewyższają

\footnotetext{
${ }^{22}$ Sygn. akt III CZP 11/16, Legalis nr 1445175.
} 
jego wartość ubezpieczeniową, ubezpieczający nie może żądać świadczenia przenoszącego wysokość szkody. Między ubezpieczycielami każdy z nich odpowiada w takim stosunku, w jakim przyjęta przez niego suma ubezpieczenia pozostaje do łącznych sum wynikających z podwójnego lub wielokrotnego ubezpieczenia.

Pierwszym argumentem dotyczącym możliwości zastosowania art. $824^{1}$ k.c., który przytoczył Sąd Najwyższy w powyższej uchwale i który należy zaaprobować, jest okoliczność, iż mimo że przepis ten posługuje się kategorią wartości ubezpieczeniowej, kiedy to na gruncie ubezpieczenia OC występuje inna instytucja - suma ubezpieczeniowa (suma gwarancyjna), instytucje te pełnią tożsame cele. Nie oznacza to jednak, że pełnią funkcję analogiczną. W przypadku ubezpieczenia mienia nie można wykluczyć sytuacji, w której suma ubezpieczenia różni się od wartości ubezpieczeniowej. Gdy suma ubezpieczenia okaże się niższa, to właśnie ona (nie zaś wartość ubezpieczeniowa) wyznaczy górny limit odpowiedzialności ubezpieczyciela. Nie można jednak zapominać, że art. $824^{1}$ k.c. można wprost stosować wyłącznie do ubezpieczeń majątkowych innych niż ubezpieczenia OC. Gdyby art. $824^{1}$ k.c. posługiwał się instytucją sumy ubezpieczeniowej, znalazłby zastosowanie wprost do ubezpieczeń OC. Celem zaś tego artykułu jest poszukiwanie możliwości analogicznego zastosowania tegoż przepisu.

Jak trafnie zauważył Sąd Najwyższy, w przypadku OC wartość szkody i fakt ewentualnego podwójnego ubezpieczenia jest znany dopiero po wyrządzeniu szkody objętej ochroną ubezpieczeniową (ex post), kiedy to w przypadku ubezpieczeń majątkowych posługujących się kategorią wartości ubezpieczeniowej wysokość szkody i ewentualna okoliczność istnienia podwójnego ubezpieczenia jest znana od początku (ab initio). Nie można jednak stracić z pola widzenia, że na etapie rozliczeń regresowych między ubezpieczycielami przy OC wysokość szkody jest już znana, a zakres odpowiedzialności ubezpieczycieli jest każdorazowo limitowany instytucją sumy gwarancyjnej. Oznacza to, że na gruncie ubezpieczeń OC każdorazowo można wskazać ekwiwalent wartości ubezpieczeniowej i w konsekwencji ustalić, że doszło do podwójnego ubezpieczenia.

Nie ma przy tym znaczenia, że ubezpieczyciele nie zawarli jakiegokolwiek porozumienia w zakresie wzajemnych rozliczeń na wypadek podwójnego ubezpieczenia, bowiem art. $824^{1} \S 1$ k.c. nie uzależnia wzajemnego rozliczenia ubezpieczycieli od zawarcia jakiegokolwiek porozumienia. Ubezpieczyciele rozliczają się zatem wewnętrznie w proporcji do przyjętych sum gwarancyjnych.

Drugim argumentem, jaki przedstawił Sąd Najwyższy i który należy zaaprobować, jest sposób unormowania przez ustawodawcę instytucji podwójnego ubezpieczenia w innym akcie normatywnym - ustawie z dnia 18 września 2001 r. Kodeks 
morski ${ }^{23}$. Zgodnie z art. 303 Kodeksu morskiego, jeżeli ubezpieczono przedmiot ubezpieczenia od tego samego niebezpieczeństwa na ten sam okres u dwóch lub więcej ubezpieczycieli na sumy, które łącznie przewyższają wartość ubezpieczenia, albo jeżeli z innych względów suma odszkodowań, które należne byłyby odrębnie od każdego z tych ubezpieczycieli, przekraczałaby szkodę podlegającą wyrównaniu (ubezpieczenie wielokrotne), ubezpieczający może żądać od każdego z tych ubezpieczycieli zapłaty odszkodowania zgodnie z zawartą umową, jednak nie może otrzymać od nich łącznie odszkodowania przewyższającego szkodę (§ 1). W stosunkach wzajemnych między ubezpieczycielami udział w odszkodowaniu ponoszony przez każdego $\mathrm{z}$ nich określa się $\mathrm{w}$ proporcji między odszkodowaniem, które musiałby zapłacić, gdyby był jedynym ubezpieczycielem, a sumą odszkodowań, które obciążałyby każdego z tych ubezpieczycieli, zgodnie z zawartą umową (§ 2). Przepis ten również posługuje się inną niż wartość ubezpieczeniowa instytucją, mimo to reguluje podwójne ubezpieczenie. Oznacza to, że aby możliwe było stosowanie regresu między ubezpieczycielami przy podwójnym ubezpieczeniu nie jest konieczne posługiwanie się przez przepis instytucją wartości ubezpieczeniowej.

Trzecim argumentem, którym trafnie posłużył się Sąd Najwyższy, jest analiza procesu legislacyjnego poprzedzającego wprowadzenie art. $824^{1} \S 1$ k.c. do porządku prawnego oraz intencje ustawodawcy. Analizując ten proces nie można stwierdzić, że intencją ustawodawcy było pozbawienie ubezpieczycieli prawa do rozliczeń regresowych. Ponadto należy zauważyć, że skoro ustawodawca uznał, że ubezpieczycielowi przysługuje roszczenie regresowe w przypadku ubezpieczenia dobrowolnego majątkowego, gdyż odpowiada to zasadzie sprawiedliwości i równego traktowania podmiotów względem prawa, to takiej zasadzie służy również zastosowanie $\mathrm{w}$ drodze analogii art. $824^{1} \S 1$ k.c. do podwójnego ubezpieczenia OC. Nie można również zapominać, że ustawodawca dążył do poszerzenia ochrony ubezpieczającego, przy jednoczesnym zachowaniu interesów ubezpieczycieli. W przypadku przyjęcia stanowiska o braku możliwości kierowania przedmiotowych roszczeń regresowych, zakłady ubezpieczeń - mając na uwadze względy ekonomiczne - mogłyby dążyć do ograniczenia tej ochrony.

Dodać należy jeszcze czwartą rację przemawiającą za możliwością stosowania w drodze analogii art. $824^{1} \S 1$ k.c. - treść art. 22 ust. 1 ustawy z dnia 22 maja 2003 r. o ubezpieczeniach obowiązkowych, ubezpieczeniowym funduszu gwarancyjnym i polskim biurze ubezpieczycieli komunikacyjnych ${ }^{24}$. Zgodnie z tym przepisem, do umów ubezpieczenia obowiązkowego, w sprawach nieuregulowa-

\footnotetext{
${ }^{23}$ Dz. U. Nr 138, poz. 1545 z późn. zm.

${ }^{24}$ Dz. U. Nr 124, poz. 1152 z późn. zm.
} 
nych w ustawie, stosuje się przepisy k.c. Umowa ubezpieczenia odpowiedzialności cywilnej oraz umowa ubezpieczenia mienia dotyczą odrębnych przedmiotów ubezpieczenia, jednak nie bez znaczenia pozostaje fakt, że art. 822 k.c. (definiujący umowę ubezpieczenia OC) oraz art. $824^{1}$ § 2 k.c. (regulujący kwestię podwójnego ubezpieczenia) znajdują się w dziale II k.c. Systematyka ta uzasadnia możliwość analogicznego zastosowania art. $824^{1} \S 2$ k.c. do podwójnego ubezpieczenia OC.

Podsumowując, do roszczenia regresowego w przypadku podwójnego ubezpieczenia odpowiedzialności cywilnej należy w drodze analogii stosować art. $824^{1}$ k.c.

\section{BIBLIOGRAFIA}

\section{ŹRÓDŁA PRAWA}

Ustawa z dnia 23 kwietnia 1964 r. Kodeks cywilny, Dz.U. Nr 16, poz. 93 z późn. zm.

Ustawa z dnia 18 września 2001 r. Kodeks morski, Dz. U. Nr 138, poz. 1545 z późn. zm.

Ustawa z dnia 22 maja 2003 r. o działalności ubezpieczeniowej, Dz. U. Nr 124, poz. 1151 z późn. zm.

Ustawa z dnia 22 maja 2003 r. o ubezpieczeniach obowiązkowych, ubezpieczeniowym funduszu gwarancyjnym i polskim biurze ubezpieczycieli komunikacyjnych, Dz. U. Nr 124, poz. 1152 z późn. zm.

Ustawa z dnia 13 kwietnia 2004 r. o zmianie ustawy - Kodeks cywilny oraz zmianie niektórych innych ustaw, Dz.U. z 2007, Nr 82, poz. 557.

Rozporządzenie Ministra Finansów z dnia 9 grudnia 1992 r. w sprawie ogólnych warunków obowiązkowego ubezpieczenia odpowiedzialności cywilnej posiadaczy pojazdów mechanicznych za szkody powstałe w związku z ruchem tych pojazdów, Dz. U. Nr 96, poz. 475 z późn. zm.

Rozporządzenie Ministra Finansów z dnia 24 marca 2000 r. w sprawie ogólnych warunków obowiązkowego ubezpieczenia odpowiedzialności cywilnej posiadaczy pojazdów mechanicznych za szkody powstałe w związku z ruchem tych pojazdów, Dz. U. Nr 26, poz. 310.

\section{ORZECZNICTWO}

Uchwała składu siedmiu sędziów Sądu Najwyższego z dnia 9 marca 1974 r., sygn. akt III CZP 75/73, Legalis nr 17826.

Uchwała Sądu Najwyższego z dnia 7 kwietnia 1975 r., sygn. akt III 6/75, OSNCP 1976, nr 2, poz. 27. Uchwała Sądu Najwyższego z dnia 22 listopada 1978 r., sygn. akt III CZP 76/78, Legalis nr 21190. Uchwała Sądu Najwyższego z dnia 27 kwietnia 2001 r., sygn. akt III CZP 5/01, OSNC 2001/11/161. Uchwała Sądu Najwyższego z dnia 30 listopada 2005 r., sygn. akt III CZP 96/05, Legalis nr 71457. Uchwała Sądu Najwyższego z dnia 17 lipca 2007 r., sygn. akt III CZP 66/07, Legalis nr 84025. Uchwała Sądu Najwyższego z dnia 13 maja 2016 r., sygn. akt III CZP 11/16, Legalis nr 1445175. Uchwała pełnego składu Izby Cywilnej Sądu Najwyższego z dnia 8 października 2010 r., sygn. akt III CZP 35/10, Legalis nr 248464.

Wyrok Sądu Najwyższego z dnia 18 grudnia 1968, sygn. akt II CR 409/68, Legalis nr 13768.

Wyrok Sądu Najwyższego z dnia 20 stycznia 2000 r., sygn. akt II CKN 656/98, Legalis nr 354561. Wyrok Sądu Najwyższego z dnia 9 października 2002 r., sygn. akt IV CKN 1409/00, Legalis nr 275101. 
Wyrok Sądu Najwyższego z dnia 18 listopada 2005 r., sygn. akt IV CKN 203/05, [w:] www.saos. org.pl [dostęp: 31.10.2018].

Wyrok Sądu Najwyższego z dnia 20 października 2006 r., sygn. akt IV CSK 125/06, Legalis nr 95812. Wyrok Sądu Najwyższego z dnia 16 października 2014 r., sygn. akt III CSK 302/13, Legalis nr 1126749.

Wyrok Sądu Apelacyjnego w Krakowie z dnia 9 stycznia 2015 r., sygn. akt I ACa 1388/14, Legalis nr 1213588.

Wyrok Sądu Apelacyjnego w Krakowie z dnia 10 maja 2017 r., sygn. akt I ACa 1615/16, Legalis nr 1713168.

Wyrok Sądu Okręgowego w Krakowie z dnia 3 grudnia 2014 r., sygn. akt II Ca 1720/14, [w:] www. saos.org.pl [dostęp: 31.10.2018].

\section{LITERATURA}

KALIŃSKI Maciej: Umowa ubezpieczenia, [w:] Adam Brzozowski, Jacek JASTRZĘBSKI, Maciej KALIŃSKi [I IN.]: Zobowiązania. Część szczegółowa, Warszawa: Wolters Kluwer Polska 2017, s. 319-334.

KRAJEWSKI Marcin: Umowa ubezpieczenia, Warszawa: C.H. Beck 2004.

Krajewski Marcin: Umowa ubezpieczenia. Art. 805-834 KC. Komentarz, Warszawa: C.H. Beck 2016. OrLICKI Marcin: Umowa ubezpieczenia, Warszawa C.H. Beck 2002.

Orıowski Cezary: Dopuszczalność stosowania zasad proporcji w sytuacji niedoubezpieczenia, Monitor Ubezpieczeniowy 50 (2012).

RADWAŃSKi Zbigniew, PANOwicZ-LiPSKa Janina: Zobowiązania - część szczegółowa, Warszawa: C.H. Beck 2017.

Sobolewski Przemysław: Komentarz do art. 518 k.c., [w:] Kodeks cywilny. Komentarz, red. K. Osajda, Legalis/el. 2018.

\section{PROJEKTY}

Rządowy projekt ustawy o zmianie ustawy - Kodeks cywilny, ustawy o działalności ubezpieczeniowej oraz ustawy o ubezpieczeniach obowiązkowych, Ubezpieczeniowym Funduszu Gwarancyjnym i Polskim Biurze Ubezpieczycieli Komunikacyjnych, Druk sejmowy nr 353 z dnia 16 lutego 2006 r. i nr 353 - A z dnia 31 maja 2006, Sejm V Kadencji, [w:] orka.sejm.gov.pl [dostęp: 20.10.2018].

\section{PODWÓJNE UBEZPIECZENIE TEGO SAMEGO PRZEDMIOTU UBEZPIECZENIA PRZY UBEZPIECZENIU ODPOWIEDZIALNOŚCI CYWILNEJ}

\section{Streszczenie}

W artykule przedstawiona została instytucja podwójnego ubezpieczenia. Autorka scharakteryzowała umowę ubezpieczenia - pojęcie, obowiązki stron umowy i rodzaje ubezpieczeń. Następnie opisano instytucję podwójnego ubezpieczenia w Kodeksie cywilnym oraz wykazano istnienie luki w prawie w przypadku podwójnego ubezpieczenia odpowiedzialności cywilnej.

Kolejno autorka przeanalizowała możliwość analogicznego stosowania art. 518 k.c., art. $376 \S 1$ k.c., art. 441 k.c., art. 828 k.c., art. 405 k.c. oraz art. $824^{1}$ k.c. w celu wyeliminowania wspomnianej luki w prawie. W ten sposób poczyniono analizę przepisów prawnych poprzez możliwość ich analogicznego zastosowania w przypadku podwójnego ubezpieczenia odpowiedzialności cywilnej, 
której efektem jest wykazanie przez autorkę, że do omawianej instytucji zastosowanie powinien znaleźć art. $824^{1}$ k.c. stosowany per analogiam.

Słowa kluczowe: umowa ubezpieczenia; podwójne ubezpieczenie; ubezpieczenie odpowiedzialności cywilnej; ubezpieczenie mienia; wykładnia prawa

\section{THE INSTITUTION OF DOUBLE INSURANCE IN THE LIABILITY INSURANCE}

\section{Sum mary}

The article presents the definition of double insurance. The insurance contract has been described in general by the author. The insurance contract, the rights and duties of the parties and all types of insurance contracts have been defined in the article. Moreover, the author depicts the institution of double insurance existing in the Civil Code and demonstrates the loophole in the insurance law concerning the double liability insurance.

Furthermore, the provisions of: art. 518, art. $376 \S 1$, art. 441, art. 828, art. 405 and art. $824^{1}$ of the Civil Code have been revised for the purpose of finding their analogical application for double liability insurance. It has been discovered that the art. $824^{1}$ of the Civil Code applies by analogy to the institution of double liability insurance.

Key words: insurance contract; double insurance; liability insurance; property insurance; interpretation of the law 